\title{
Hva er en forfatter?
}

Engelsk oversettelse på www.tidsskriftet.no

Jeg snakker mye med stipendiater og yngre forskere. Ofte kommer samtalen inn på forfatterskap, og mange har en historie å fortelle. Den vanligste er den om en seniorforsker som krever urettmessig forfatterskap. Ofte har striden om hvem som skal stå i forfatterlisten kjørt seg fast. Uryddighet rundt forfatterskap kan være et symptom på usunt forskningsmiljø.

Det kan virke underlig, nesten uforståelig, at spørsmål om forfatterskap kan sette sinnene slik i kok blant medisinere og forskere i tilgrensende fag. Forskere innen humaniora og samfunnsvitenskap rister bare på hodet - hos dem dyrkes fortsatt i stor grad eneforfatterskapet. Der gjelder fortsatt ordbokdefinisjonen av en forfatter: Den som skriver en tekst. Slik er det ikke i medisin og naturvitenskapelige fag.

Det er ikke så rart at spørsmålet er følsomt. Det dreier seg jo om selve valutaen i forskningen. I økende grad må man forsvare sin eksistens som forsker ved å publisere. «Publiser eller forsvinn» er ment bokstavelig. Det gjelder både karriere og penger. Mye står på spill dersom man urettmessig utelukkes som forfatter og vice versa.

I medisinsk forskning har forfatterskapskriteriene fra International Committee of Medical Journal Editors (ICMJE), også kalt Vancouvergruppen, fått stort gjennomslag. På papiret virker det greit: Forfatterskap skal baseres på a) Vesentlige bidrag til idé og utforming, eller datainnsamling, eller analyse og tolking av data, b) Utarbeiding av selve manuskriptet eller kritisk revisjon av artikkelens intellektuelle innhold og c) Godkjenning av artikkelversjonen som skal publiseres. Samtlige kriterier ( $a, b$ og c) må oppfylles. Selv om innføringen av disse reglene har vært viktig, er problemet med forfatterskap langt fra løst. Reglene gir rom for tolking, og mange følger dem ikke. Urettmessige forfatterskap kan ha mange former, bl.a. gaveforfatterskap, gjesteforfatterskap og spøkelsesforfatterskap (på engelsk: gift, guest og ghost authorship). Forfatterskapsspørsmål er de siste årene drøftet en rekke ganger i Tidsskriftet (1-5). Hvor komplekst og krevende dette er, får man et innblikk i ved å ta en titt i databasen til Committee on Publication Ethics (6).

Rekkefølgen på navnene i forfatterlisten er ikke tilfeldig. Det synes å være enighet om at førsteforfatterskapet går til den som har gjort den største jobben, og det gir følgelig størst meritt. Hvem som skal stå på de andre plassene, er mer uklart. Gir det mer meritt å være andreforfatter enn sisteforfatter? I hvilken rekkefølge skal øvrige forfattere stå - etter innsats (hvem skal i så fall vurdere det) eller etter alfabetet? Vancouver-reglene gir, paradoksalt nok, ingen veiledning i slike spørsmål (7). Praksis varierer mellom ulike spesialiteter, det meste er basert på tradisjoner og kutyme. I de siste årene har mange tidsskrifter åpnet for delt førsteforfatterskap, dvs. at de første på forfatterlisten skal få like mye meritt og at dette markeres i artikkelen. Dette gjelder også i Tidsskriftet (fra nr. 6/2008).

Da jeg begynte i Tidsskriftet i 2000, ble papirmanuskripter sendt i posten mellom redaksjonen og kontaktforfatteren. Ved manusinnsending måtte medforfatterne signere et oversendelsesbrev. Deretter var det ingen kontakt mellom dem og redaksjonen - vi tok det for gitt at kontaktforfatteren holdt medforfatterne orientert om manusprosessen. Etter flere skandaler, bl.a. Sudbø-saken, innførte vi fra juni 2008 en ordning der alle medforfatterne automatisk får beskjed per e-post når et manus sendes inn og ved hver kontakt med redaksjonen frem til endelig beslutning.
Enkelte ønsker å droppe hele forfatterbegrepet og heller snakke om bidragsytere (contributorship) og garantister (guarantors). Da lages det en spesifisert liste over hva de ulike har bidratt med til manuskriptet. Forslaget ble lansert i 1997, og redaktøren i The Lancet sparte ikke på lovordene. Dette har potensial til å forandre hele strukturen på moderne vitenskap, hevdet han, og at alle fritt kan overse forfatterskapsreglene fra Vancouver-gruppen (8). Ikke alle ser det slik. Etter min mening bidrar ikke ordningen med bidragsytere og garantister med noe grunnleggende nytt. Bidragsyterne vil fremdeles bli listet som forfattere i de medisinske databasene, og ordningen er like sårbar for juks som Vancouver-reglene. Det er verdt å minne om at artikkelen som avslørte Jon Sudbøs svindel, sto på trykk i nettopp The Lancet. Likevel kan det være fornuftig at leserne făr vite hva de enkelte forfatterne har bidratt med. En slik ordning innføres nå også i Tidsskriftet. Hvem som har bidratt til en vitenskapelig artikkel er av interesse ikke bare for forskere og redaktører - det er også viktig for leserne. Tidsskriftet har allerede innført (fra nr. 9-10/2011) en ordning med minibiografier, der forfatterne angir fødselsår, stilling, arbeidssted og andre opplysninger som er relevant for artikkelen (9).

Tradisjonelt har det vært slik at de som har bidratt til et manuskript, men som ikke oppfyller forfatterskapskriteriene, kan takkes til slutt $i$ artikkelen (under acknowledgements). Imidlertid er slike takksigelser av liten verdi for dem det gjelder. For å kunne gjennomføre store prosjekter og opprettholde interessen for å delta i fremtiden er det viktig at medarbeiderne får noe igjen for innsatsen. Flere av dem vil ikke kvalifisere som forfattere. Løsningen er blitt at man oppgir noen få navngitte forfattere på vegne av en studiegruppe. I tillegg navngis studiegruppens medlemmer, som dermed blir kreditert for sitt bidrag til artikkelen (10). På norsk kan man kalle disse for «medlemmer av studiegruppen» (på engelsk: collaborators). En slik ordning etableres nå også i Tidsskriftet.

Hensikten med disse endringene er todelt: Leserne får vite hvem som har gjort hva og hvem som er ansvarlige for artikkelens innhold, og de som har bidratt til artikkelen, får den anerkjennelse de fortjener - uten at forfatterbegrepet utvannes.

\section{Erlend Hem}

erlend.hem@medisin.uio.no

Erlend Hem (f. 1970) er dr.med. og assisterende redaktør i Tidsskriftet.

Litteratur

1. Nylenna M. Forfatterskapskriteriene er endret. Tidsskr Nor Lægeforen 2000; 120: 1844

. Bjørheim J, Frich JC, Gjersvik P et al. Tidsskriftet, ekstern fagvurdering og medisinsk publisering. Tidsskr Nor Lægeforen 2006; 126: $20-3$.

3. Haug C. Forfatterskap og medforfatterskap. Tidsskr Nor Lægeforen 2006; $126: 429$. . Staff A, Thorseth M. Hva er en medforfatter? Tidsskr Nor Lægeforen 2007; 127 1959.

5. Haug C. Spøkelser i spaltene. Tidsskr Nor Legeforen 2008; 128: 1039.

6. Cases. Committee on Publication Ethics. http://publicationethics.org/cases (8.2.2012).

7. Authorship and contributorship. International Committee of Medical Journal Editors. http://icmje.org/ethical 1author.html (10.2.2012).

8. Horton R. Who should be an author? I: Hall GM. How to write a paper. 4. utg. London: BMJ Books, 2008: 112-6.

9. Forfatterveiledningen. Tidsskrift for Den norske legeforening. http://tidsskriftet.no/ Innhold/Forfatterveiledningen/Manusutforming/Foelgebrev (10.2.2012).

10. Knecht LS, Nahin AM. Study collaborators included in MEDLINE/PubMed. NLM Tech Bull 2008; nr. 361: e2. www.nlm.nih.gov/pubs/techbull/ma08/ ma08_collaborators.html (10.2.2012). 